Rev. Tadeusz Kasabuta University of Bialystok

\title{
The Officials of the Cathedral Chapter of Vilnius Before the Partition of Poland
}

Originally, the members of cathedral chapters were organizationally and structurally divided into two categories: general prelates and canons. During the early stages of organization, prelatures were simultaneously dignities and capitular offices. After the Middle Ages, however, prelatures ceased to be offices and became titular dignities instead. Due to the evolution of the structure and the development of the organization of the chapters and the ways in which they functioned, it was necessary to appoint new officials who were independent of the particular dignities. From the moment that the college of prelates and canons was founded and established in Vilnius, they functioned and acted in spiritualibus and in temporalibus by following the example of the chapter in Cracow that had existed for centuries and adapted the practices to the local conditions of Vilnius. This influence is very clear in the selection and competencies of the officials chosen for the Cathedral Chapter of Vilnius. Among the officials chosen before the partition of Poland took place, those who had the most lasting effects were the capitular procuators, inspectors of capitular goods and property, chancellors, notaries, architivists, and deputies to the Lithuanian Tribunal.

Key words: Grand Duchy of Lithuania, Vilnius, cathedral chapter, capitular procuator, chancellor, notary, archivist, Lithuanian Tribunal.

\section{Introduction}

By using the Cathedral Chapter of Cracow as its organizational and structural model, the positions, dignities, functions, and offices of the Cathedral Chapter of Vilnius bypassed the initial stages of development that were characteristic for the Polish chapters that were formed 
during the early centuries of the Middle Ages. ${ }^{1}$ From the moment that the Vilnus chapter of prelates and canons was founded and erected, they functioned and acted in spiritualibus and in temporalibus according to the example of the Cathedral Chapter in Cracow that had existed for centuries and adapted its practices to their local conditions. Whenever the Chapter was in doubt regarding a particular issue, it first referred directly to the Cathedral Chapter of Cracow and then, as time when on, to the legal practices and customs that were established in Cracow that were more or less modified into a set of statutes that was transferred to Vilnius.

Originally, the members of cathedral chapters were organizationally and structurally divided into two categories: general prelates and canons. During the early stages of organization, prelatures were simultaneously dignities and capitular offices. As time passed and moved further away from the Middle Ages, however, prelatures ceased to be offices and, instead, became titular dignities. Originally the provost, meaning the pastor, presided over and supervised the chapter, while the deacon kept watch over the Sluga Boza $n$ the Cathedral, the archdean was de facto the episcopal official of the Cathedral Chapter of Vilnius who visited parishes and examined candidates for the priesthood. The custodian took care of the treasury and the sacristy and was also responsible for ministry the within the cathedral until this responsibility was passed on to the penitentiaries, personal preachers,

History and the college of vicars. The cantor was responsible for the musical and liturgical chant, and the master of schools directed the cathedral school. As the offices evolved, the dignities bestowed on specific prelates began to be passed on either to those who chapter appointed to assist it or directly to the prelates' deputies who performed their duties. For example, the deanreceived a vice dean, the custodian-a vice custodian, the cantor-a vice cantor, the master of schools transferred his powers to an unaffiliated director of the school and school dormitories. When visiting parishes, the capitular archdeacon was more and more often replaced by the diocesan bishops themselves or suffragan bishops and, later on, by the visitators appointed by the bishop. The evolution of the structure and organization of the chapter meant that the changes and variations in way the chapter functioned

1 M. D. Kowalski, "Początki majątku krakowskiej kapituły katedralnej," in Duchowieństwo kapitulne $w$ Polsce średniowiecznej $i$ wczesnonowożytnej. Pochodzenie i funkcjonowanie elity kościelnej, ed. A. Radzimiński, Torun 2000, pgs. 69-84; W. Abraham, Organizacja Kościoła w Polsce do połowy XII wieku, Poznan 1962, pgs. 179-180, 302-305; S. Zachorowski, Rozwój i ustrój kapitut polskich w wiekach średnich, Cracow 1912, pgs. 41-45. 
made it necessary for it to appoint new officials who were not affiliated with particular dignities.

\section{The Procurator}

Because the Cathedral Chapter of Vilnius followed the structures and organization of the Cathedral Chapter of Cracow, the the offices that arose from and were connected with particular prelates as well as the offices that developed independently prelates were few in number from the very beginning and into the $18^{\text {th }}$ century. Among the independent prelates, the procurator undoubtedly played the most significant role. Although individual members of the chapter managed the praestimoniae with the help of their deputies, the management of the property that was held in common was the responsibility of the entire college, which over time appointed a separate official-the procurator-to carry out the duties related to this task. In light of original sources, it is difficult to say when the entire capitular body first collegially appointed an individual to fill this office, which was independent from any dignities bestowed on prelates. It is also difficult to assert whether this office was established by the authority of the praepositor, which S. Zachorowski suggests in his discussion of royal chapters. ${ }^{2}$ The fact this office was first noted in the capitular acts in 1503. In that year, on August 14, a canon from Vilnius named Jan from Borzeyniewa was chosen as the procurator. His powers were defined rather vaguely; he was granted full power of attorney to manage the Chapter's affairs. Whether the Chapter exercised such foresight, or whether these affairs became so numerous or the nature of these matters made it necessary to appoint someone else to manage them, the fact is that the newly created position of procurator was granted the right to take on a deputy. Perhaps, however, the office of procurator arose as a result of the existing need for someone to primarily manage the provost's affairs, since the establishment of this office corresponds to a time period when Ezram Ciołek, who rarely made an appearance in Vilnius, held it. This also seems to be the case when one considers the affairs with which the procurator, who was tasked with taking care of the sums money that were offered at the relics of the Holy Martyrs and left by the provost, was entrusted. A canon Mikołaj Żukowski, who had left Vilnius for a period of time, left

$2 \quad$ S. Zachorowski, op. cit., pgs. 193-201. 
the management of his funds to the procurator. ${ }^{3}$ It appears that the Chapter enjoyed the benefits of having a canon procurator because the scope procurator's duties continually increased; for, the procurator was inspecting the Chapter's property a decade or so later. ${ }^{4}$ After the vote in 1521, the canon Wojciech Wieleżyński was elected to the office of prosecutor, and his rights and duties were determined. According to the resolution enacted by the Chapter on September 20 of that same year, the procurator had to administer all of the Chapter's moveable and immovable goods; take care of and supervise the construction of capitular buildings; oversee the church's furnishings and equipment; collect taxes, rents, and debts owed by lessees and other subjects; and search out and enforce the necessary pentalties in the form of fines and contriutions on those who in any way harmed the functioning of the capitular benefice or who did not pay the Chapter what they owed according to the terms of a lease or any other agreement; and to carry out patrimonial judicial decisions regarding capitular goods. ${ }^{5}$

In time, the procurator was commissioned with dispensing the distribution and keeping the financial records of revenue and expenses. ${ }^{6}$ As a result, the members of the Chapter who were delegated by it to deal with different matters were required, under the penalty of losing their income while away from the cathedral, to inform the Chapter in advance if they planned to be away. ${ }^{7}$ The procurator held the keys to the capitular treasury and, when necessary, was commissioned with

History of the Church curbing the prelates and canons' frequent attempts to take funds designated for the sacristy, for the vessels and vestments needed to celebrate the Mass, and for maintaining the cathedral building, and

3 Lietuvos Mokslų Akademijos Vrublevskių Biblioteka - rankraščių skyrius (abbreviated hereafter as LMAB), f. 43-210, Acta Capituli Vilnensis (abbreviated hereafter as ACV), vols. 1-2 (1502-1546), k. 15; J. Kurczewski, Kościót zamkowy czyli katedra wileńska w jej dziejowym, liturgicznym, architektonicznym i ekonomicznym rozwoju, Part 3, Wilno 1916, pgs. 5-6.

LMAB, f.43-210, ACV, vols. 1-2 (1502-1546), k. 32.

Ibid, k. 43-44, 56 .

LMAB, f.43-210, ACV, vols. 1-2 (1502-1546), k. 66; LMAB, f.43-216, ACV, vol. 8 (1602-1624), pg. 452; LMAB, f.43-237, ACV, vol. 29 (1767-1777), pgs. 231-232.

Since the members of the Chapter were more frequently began to neglect their obligation to reside by the cathedral, using capitular affairs as their excuse for being away when they were gone, in fact, for personal reasons (although a few members did, in fact, attend to capitular affairs while away), and, consequently, would collect refection for their trips, the chapter decided to specify "away on the chapter's business" during the spring session in 1627. LMAB, f.43-217, ACV, vol. 9 (1625-1632), k. 39-39v. 
include it with their own income. ${ }^{8}$ In 1624 , the procurator was handed the keys to the cathedral and ordered keep them in a safe place in his apartment. $^{9}$

Since the procurator was forced to conduct court proceedings by virtue of his office, he was in charge of the capitular archives and, as such, had access to and used the Chapter's smaller seal until the position of chancellor and its corresponding powers were established. Therefore, the procurator was free to use the seal only to seal letters and copies of the decisions that the Chapter made, and if he abused this privilege, then his annual income would be lowered and the authenticated documents would be rendered null. ${ }^{10}$

The procurator reported directly to the Chapter and was accountable to it. After serving for one year, he was required to submit a report of his activities to the members of the Chapter during its session before February $2 .{ }^{11}$ After reviewing the report, the Chapter would vote either in favor of or against the procurator serving another year term. Most often, after giving a positive report, the procurator was elected to serve in his role for another year. However, the opposite was also true: when the procurator delivered report that was unsatisfactory to the Chapter, he was not elected to serve another term or he dismissed from his office. The procurator's annual report was one of the most important acts that took place during the Chapter's general spring session. In fact, the procurator's annual report was one of the most important acts of the Chapter's general spring session that the content of this report was included (although not always) in the final protocol of the session. ${ }^{12}$

At the capitular session that took place in autumn on October 10, 1528 , the chapter determined the traits that candidate for procurator should possess. The chapter decided that, before all else, the candidate should in no way have harmed the public good, be prudent, "have a stable character, ad not be wasteful, inclined to quarrel, and disagreeable to his brothers." If the candidate habitually failed to meet these

LMAB, f.43-210, ACV, vols. 1-2 (1502-1546), k. 66.

LMAB, f.43-216, ACV, vol. 8 (1602-1624), pg. 460.

LMAB, f.43-210, ACV, vols. 1-2 (1502-1546), k. 92.

"Summaryjny wypis z protokołów Kapituły Katedralnej Wileńskiej od r. 1501 do r. 1783 Października 22, przez i. w. Xawierego Bohusza, Prałata Kantora Kathedry Wileńsiey uczyniony," in Opisanie rukopisnago otdielenia Wilenskoj Publicznoj Biblioteki, wypusk 1, Wilna 1895, s. 52.

2 LMAB, f.43-210, ACV, vols. 1-2 (1502-1546), k. 43; 60, 66-66v. 
conditions, then was punished by being removed from his office before the end of his term and refused refection for two months. ${ }^{13}$

It soon proved true that one official was not able to meet these requirements; therefore, a second procurator-the canon Stanisław Dąbrówka-was elected in $1522 .{ }^{14}$ That same year, during the autumn chapter session, two inspectors-so-called "divisors" (equitantes) of the capitular goods in Russia were elected to assist them and their duties drawn up on October 13. The divisors' duties overlapped with those of the procurators, and they were limited only territorially to the capitular goods that were furthest from Vilnius. It is no coincidence, then, that the Bishop of Kiev and prelate curator of Vilnius, Jan Filipowicz, was one of them. ${ }^{15}$ Soon after, in the 1620 s, the Chapter determined that only one divisor was necessary to address the current needs in Russia, and this decision was confirmed during the general session and recorded in the acts on October $10,1528 .^{16}$

Until the autumn of 1528, procurators and the divisor did not receive a fixed permanent salary; instead, they received an income that was due to them based on their affiliation with the capitular college. ${ }^{17} \mathrm{In}$ 1518 , after inspecting the capitular properties and collecting the rents and taxes from them, they ceased using the means of transportation that they should be given and, instead, used their own team of horses, explaining to the Chapter that "taking the horses of impoverished subjects is onerous to them [the procurators]." The men were paid

History for the trouble of having to collect payments from (serfs) inclinatoria, of the Church otherwise known as the so-called "benefice of obeisance," which they were required to deposit in the communal capitular coffer. In the $16^{\text {th }}$ century, the only financial compensation that the procurator received was a "reward" in the amount of 10 kopa of Lithuanian groszy, which had increased to 300 kopa of Lithuanian groszy annually in the second half of the $18^{\text {th }}$ century. ${ }^{18}$ Because this was only a reward, the Chapter could refuse to give it if the procurator did not satisfactorily carry

\footnotetext{
$13 \quad$ Ibid, k. 120-120v.

$14 \quad$ Ibid, k. 47.

$15 \quad$ Ibid, k. 56.

$16 \quad$ Ibid, k. 120.

17 Ibid.
}

18 LMAB, f.43-968, Księga dochodów i wydatków, 1771, k. 6v; LMAB, f.318-34673, Opłata refekcjów, 1793, k. 4v; LMAB, f.43-1243, Księga przychodów i rozchodów, $1795 / 1796$, k. $11 \mathrm{v}$. 
out his duties or sinned by overzealously collecting debts, which the chapter looked on with disapproval. ${ }^{19}$

\section{The Chancellor}

The scope of the procurator's duties did not significantly change after the Bishops Eustace Wołłowicz and Abraham Woyna required that the Chapter appoint a canon Chancellor. ${ }^{20}$ In 1629 , prelates and canons protested this decision, emphasizing that the office contradicted the statues, which did not provide for this particular dignity and office. The Chapter's correspondence with the bishops placed particularly emphasized the fact that the act of introducing the office of a chancellor who had the same royal powers into the Chapter would abolish the office the capitular procurator, which was provided for in the statutes. ${ }^{21}$ The Chancellor who was ultimately introduced into the Chapter received the last stall in the cathedral and had no prospect of being promoted, which the acts from 1620-30s confirm, since they say nothing about the extent of the chancellor's rights and duties..$^{22}$ The act that established the office of Chancellor not only did not abolish the office of the Chapter prosecutor, it barely diminished the scope of the prosecutor's powers and duties. The Chancellor was the bishop's man, meaning that he was an episcopal official and his de iure duties were to tend to the diocesan archives and the productions of the episcopal (and not capitular) chancery. This office was associated with the capitular chancery to the degree that both the diocesan and capitular archives were interdependent. In practice, however, as the central administrative bodies of the Diocese of Vilnius, both archives remained under the Chapter's care and, thereby, the procurator's supervision, until the middle of the $17^{\text {th }}$ century. ${ }^{23}$ The role of the diocesan chancellor and member of the capitular body simultaneously became clear only after the Moscow army devastated the church's goods from 1656-1662. Somewhat decimated but still saved and basically intact,

LMAB, f.43-210, ACV, vols. 1-2 (1502-1546), k. 120.

T. Kasabuła, "Kanclerz diecezjalny w kapitule katedralnej wileńskiej w okresie przedrozbiorowym," in "W tym który umacnia:" Księga Pamiatkowa ku czci J. E. Ks. Bp. Prof. Edwarda Ozorowskiego, ed. J. Zabielski, Bialystok 2004, pgs. 304-308.

21 LMAB, f.43-217, ACV, vol. 9 (1625-1632), k. 132v.-133; J. Kurczewski, Biskupstwo wileńskie od jego założenia aż do dni obecnych, Wilno 1912, pgs. 381-382.

LMAB, f.43-708, Wiadomość o stanie kanclerstwa wileńskiego, b.d., k.nlb.

Opisanije rukopisnogo otdielenija Wilenskoj Publicznoj Biblioteki, vol. 1, Wilna 1895, pgs. 33-34. 
the capitular archive needed to be put into order quickly because the materials contained within the archive, particularly the documents concerning the foundation of the chapter, were necessary throughout the ongoing recovery process. ${ }^{24}$

After all of the files of both the diocesan and capitular archives were taken to Vilnius, they were permanently separated from each other and placed into two separate rooms within the cathedral. The procurator oversaw the capitular archives, while the episcopal chancellor oversaw the diocesan archives. The Chapter, however, still felt obligated to oversee both archives because of its keen interest in the successful outcome of court proceedings that the presbyters were leading. It also felt responsible for ensuring the safe keeping not only of its own but also of all of the church benefices within the diocese. ${ }^{25}$

During the 1660s, the Chapter began to value the office and person of chancellor and motivate him to fulfill his responsibility for the collections within the diocesan archives. On May 12, 1666, the Chapter approached Canon Wojciech Beynart with the request that he voluntarily take the place of Chancellor Canon Wawrzyniec Mocarski, who commendably prepared the archives for evacuation from Vilnius, after his death and remain in Vilnius despite the threat of the next Moscow invasion and assist the clergy from the diocese who were conducting their court proceedings. ${ }^{26}$ Two years later, on the occasion of Bishop

History Alexander Sapieha's ingress into the cathedral of Vilnius on August 26, the Chapter approached the bishop and demanded that he encourage his chancellor to work. Given this opportunity, the Chapter reminded the leader of the diocese that the office chancellor was established to assist all parish priests involved in cases at the Tribunal and at the episcopal court. For, as it was written, the bishop as the main "actor and patron of the entire diocese" should ensure that parish funds "were not lost." The Chapter also wrote further that the chancellor was obliged to take all the necessary files from the archives and provide them to the clergy who were involved in the cases. In order to improve how to archive functioned, the chancellor should create a register of all of the documents stored in the archive and prepare them for the judges to use "statum causae." 27 This scope of the chancellor's duties made it necessary for him to collaborate closely with the Chapter, without 
whose help he would be unable to complete the documents that the court needed for its proceedings, and particularly because a number of the founding documents were stored in the chapter archive for which the Chapter's procurator was responsible. Given the chancellor's status within the diocese, his powers and duties depended on both the bishop, since the chancellor was de iure an official of the chancery, and on the Chapter, to which he belong and on which he de facto depended by virtue of his office. The chancellor's vague place within the diocese's administration was also reflected in an oath from the $17^{\text {th }}$ entury that was added to the statutes at the end of the $16^{\text {th }}$ century that the chancellor swore before both the bishop and the chapter. The chancellor first swore to keep the capitular secret. Then he promised to faithfully and diligently guard the current episcopal archives, the diocesan archives, and the capitular [sic!] archives, and that he would not lend out or make available any of the documents contained therein without the bishop and Chapter's express consent. ${ }^{28}$

After returning to Vilnius in 1662 , the Chapter repeatedly recorded its dissatisfaction with the chancellor's job as the guardian of the diocesan archives and the assistant to clergy involved in court proceedings. During the second half of the $17^{\text {th }}$ century and throughout the $18^{\text {th }}$ century, the chancellor was regularly admonished, which was recorded in the minutes for the sessions. Generally, these admonitions pertained to the chancellor's gross negligence in fulfilling his duties. Explicit allegations against the chancellor were recorded in $1673,{ }^{29}$ $1678,{ }^{30}, 1697,{ }^{31}$ and $1706 .{ }^{32}$

Generally speaking, the Chapter's dissatisfaction resulted from the chancellor's continual absence. In order to put an end to this issue and to involve the chancellor more closely with the cathedral-in other words, in order to control him more effectively-the chancery was incorporated into the Chapter by including his praestimonium with his refection. This measure would curtail the chancellor's self-will and force him to be present, because, if he was absent, then he would cease to receive refection for the amount of time that he was not present at services, at which he was obligated to be present by the power of

$28 \quad$ LMAB, f.43-155, Statuta inclitae Ecclesiae Cathedralis tam a Venerabili Capitulo quam eius Pontificibusedita tum a Sanctissima Sede Apostolica confirmata, [ok. 1584], (Forma iuramenti a cancellario dioecesano praestandi), k. 36.

$29 \quad$ LMAB, f.43-224, ACV, vol.16 (1672-1673), pg. 89.

$30 \quad$ LMAB, f.43-225, ACV, vol. 17 (1673-1681), pg. 517. 
the founding document. ${ }^{33}$ This proposed solution was devised during the session that took place on October 12, 1742; however, it was later overlooked by the chancery of Bishop Michał Zienkiewicz and never came to fruition..$^{34}$ Although rebukes, requests, and threats regarding the chancellor continued to appear repeatedly in the meeting minutes of the capitular sessions, no solution could be found to make the chancellor obey and force him to do his job. This problem preoccupied the Chapter, and the chancellor's continual absence and, consequently, the people's lack of access to the archive and the documents that they needed to borrow was a source of anguish and anger for the capitular procurator throughout the entire $18^{\text {th }}$ century. It is not surprising, therefore, that some of the neglected capitular had gone missing, were called into question because no one had documented who had the right to them, and soon fell into the hands of secular claimants. ${ }^{35}$ In this situation, the Chapter tried to recover, secure, and control access to archival resources once again by ordering the chancellor to have a sworn deputy (vice-chancellor) in $1745 .{ }^{36}$ This effort, however, was of little use because the Chapter threatened to deprive the chancellor of his office in $1748 .{ }^{37}$ In 1772 , facing the threat of losing part of their goods due to the partition of Poland, the Chapter issued the same warnings and ordered the chancellor to maintain a sworn vice-chancellor. Anticipating that the chancellor would fail to obey, the Chapter took it upon itself the difficult work of putting the archives in order. ${ }^{38}$

\section{The Notary}

When the procurator-the official guardian of the chapter archivewas busy inspecting capitular properties and the chancellor was not fulfilling his duties, the role of notary expanded, and this office soon became essential for the chancery of the Cathedral Chapter of Vilnius to function. This official appeared in the Chapter's acts for the first time at the beginning of the $16^{\text {th }}$ century when the minutes for their meetings were first drawn up. The following individuals were noted in the acts to be the first capitular notaries: Jan from Ślubów, the public

\footnotetext{
33 LMAB, f.43-234, ACV, vol. 26 (1739-1744), pgs. 303-304.

$34 \quad$ Ibid, pg. 304.

35 LMAB, f.43-235, ACV, vol. 27 (1744-1752), pg. 41.

36 Ibid.

$37 \quad$ Ibid, pg. 235. 
and capitular notary from 1510-1522;39 Teofil from Zakroczym, the capitular notary from 1514-1522 who settled in the rectory in Niemenczyn sometime before $1524 ;^{40}$ and Jan from Cracow, the public notary and capitular recorder from 1521-1524 who served as the pastor of the parish in Świrany starting in $1524 .{ }^{41}$ The tenor of the capitular acts that were recorded during this time suggest that the office of notary was entrusted ad hoc to one or more distinguished and respected priests within the Diocese of Vilnius. This conclusion is supported by the fact that, on July 11, 1522, the capitular notary recorded in the acts that a certain Salomon Wojciech Ciszkowski-a priest from the Diocese of Plock and an apostolic notary public, who had a Bachelor's degree in Liberal Arts-was introduced as the replacement for the former notary Jan from Cracow. ${ }^{42}$ Thus, in just a few months, the office of capitular notary was successively appointed to three different priests. The reason for this state of events could have been the fact that the priests who were appointed to the office of notary did not-by virtue of their title-receive a permanent salary; therefore, the only income they received was from their own parish benefice, which obliged them to reside at their parishes. This is the reason that the aforementioned notary and pastor of the parish in Niemenczyn, Teofil of Zakroczym, gave for his resignation. In 1527, when the Chapter notary Salomon Wojciech Ciszkowski suddenly "disappeared to no one knows where" after failing to repay his debt to the Chapter, the office was appointed to Fr. Mikołaj from Łomża, who served as the notary of the Capitular Chapter of Vilnius until at least 1541 (but perhaps longer), since the History subsequent notary is not recorded in the acts until 1550. Fr. Mikołaj's successor, Fr. Trojan Mikołaj from Chrościeniewicz, had a Masters in Liberal Arts and was the rector of the cathedral school in Vilnius. ${ }^{43}$ Thus, with the nomination of Mikołaj from Eomża as the capitular notary, the practice of ad hoc appointments of notaries ceased, since the documents do not show further frequent changes in the personnel appointed to this office. It is likely that this change came about because the Chapter determined that the notary should charge a fee every time he had to make entries in the records and prepare copies of documents

\footnotetext{
39 LMAB, f.43-210, ACV, vols. 1-2 (1502-1546), k. 15.

$40 \quad$ Ibid, k. 38.

$41 \quad$ Ibid, k. $38-39 \mathrm{v}$.

42 Ibid, k. 47-47v.

$43 \quad$ LMAB, f.43-211, ACV, vol. 3 (1550-1560), k. 1.
} 
and extracts from the acts. ${ }^{44}$ As the capitular chancery grew, the duties of the notary increased. Therefore, the decision was made to involve the notary more in the Chapter house. The incentive for this involvement was a fixed remuneration for the work that the notary would do during the chapter sessions. In 1701, the notary received a one-time consolation payment of 50 Polish złoty. ${ }^{45}$ Over time-probably during the first half of the $18 \mathrm{~h}$ century - the chapter determined that the notary would receive a permanent pension of 300 Polish florins annually. ${ }^{46}$ Because of inflation, this amount was increased to 500 Polish florins in $1759 .{ }^{47}$ And in 1771, (after King Stanisław Poniatowski enacted monetary, where 1 Polish florin became equivalent to 1 Polish złoty) the capitular notary received 800 Polish złoty, which remained his pension until the end of the First Polish-Lithuanian Commonwealth. ${ }^{48}$

The notary never belonged to the Chapter, even though he participated in its sessions as a recorder. This is the reason why the notary swore an oath to keep the Chapter's secret, meaning that he would not disclose in writing, speech, or deed the matters that were discussed during the Chapter's sessions. He also promised to accurately and faithfully record all of the Chapter's acts, decrees, statutes, and resolutions; to prepare extracts and copies of the acts that were faithful to the original documents; and to not commit forgery. ${ }^{49}$

The notary's main duty was keep the Chapter's records (i.e., a book

History containing the minutes from the general and particular sessions, to which more important documents and some reports on the state of bona mensae and bona praestimoniales were recorded in extenso. $\mathrm{He}$ also prepared the drafts of capitular documents and, after the capitular members who were present at the sessions approved these drafts, he drew up the original documents and sealed them. ${ }^{50}$

\footnotetext{
$44 \quad$ LMAB, f.43-210, ACV, vol. 1-2 (1502-1546), k. 28.

$45 \quad$ LMAB, f.43-228, ACV, vol. 20 (1698-1709), k. 68.

LMAB, f.43-740, Rejestr tak intraty rocznej [...] jako i expens tejże intraty, 17091711, k. 3.

LMAB, f.43-236, ACV, vol. 28 (1753-1766), pg. 272.

LMAB, f.43-968, Księga przychodów i wydatków, 1771, k. 6v.; LMAB, f.318-34673, Opłata refekcjów, 1793, k. 4v.

LMAB, f.43-155, Statuta inclitae Ecclesiae Cathedralis [ok. 1584], k. 35v. 


\section{The Archivist}

The office of archivist-an official who collaborated closely with the procurator and the notary-was established on June 2, 1755, when the capitular archivist was sworn in. In a resolution that was enacted on this day, the Chapter instructed the newly appointed archivist, Fr. Grudziński, to review, organize, and register all documents contained within the capitular archives. The Chapter also ordered Fr. Grudziński to guard the archive; lend out the relevant documents (once he has received them) to penitents; and ensure that the files were returned on time. The Chapter gave the archivist 800 Polish zloty for his yearly pension, and, if the archivist agreed to assist the procurators at court, then he was promised an additional 200 Polish zloty. The newly appointed official assisted the procurator by giving him the prepared acts that the procurator would need in order to conduct court proceedings. As such, he was directly responsible to the procurator and took on part of his duties, which, in the habitual absence of the diocesan chancellor, were delegated to the capitular notary. ${ }^{51}$ The contents of the capitular acts from the second half of the $18^{\text {th }}$ century seem to suggest that this was a good move. The archvist, who was paid well and constantly controlled by the Chapter, resided next to the cathedral, which made it easier for him to access the acts stored in the archive and keep the archive in order. The archivist was severely reprimanded by the Chapter only once in 1766 when, without the Chapter's knowledge, performed a favor for his pastor and made the acts available to Bishop Massalski. An internal investigation into this case revealed that this was not the first time that the archivist had performed such a favor. In response, the Chapter reprimanded the archivist, admonished the procurator for not supervising his subordinate, demanded that the keys to the archive be taken from the archivist, and ordered that no one be given access to the archive, especially the current archivist, without the knowledge and consent of the Chapter until further notice. ${ }^{52}$ Needless to say, although the archivists who followed were unable to recover the acts that had been borrowed or organize the archive in a manner that completely satisfied the Chapter, materials from the archive were permanently accessible. The bothersome flaw of this office was the fact that archivists readily kept archival documents that were currently being used in their own living quarters. This was not a problem when the archivist was at work. The situation became complicated, however,

LMAB, f.43-236, ACV, vol 28 (1753-1766), pgs. 112-113. 
when the archivist resigned from his office or, even worse, died suddenly. The Chapter founds itself in this situation in 1772 when the former archivist and current vice chancellor, Fr. Chrzczonowicz, had at his disposal the original founding documents and died unexpectedly. To this day no one knows whether anyone managed to secure the archival materials in his apartment in time. ${ }^{53}$ It appears that Fr. Marcin Mordas-a priest who was appointed capitular archivist on October 6, 1780 and who fulfilled both the offices of notary and archivist for 15 years-was the most honorable figure among the archivists. ${ }^{54}$ Only a careful examination of the minutes from the capitular sessions from this time period reveal his essential but undervalued role in recovering Chapter property that had been lost due to the partitions. ${ }^{55}$

\section{The Deputies to Tribunal of the Grand Duchy of Lithuania}

The Cathedral Chapter of Vilnius had two representatives from among its members-one deputy was appointed by the Chapter and the other appointed by the bishop-who were part of the Tribunal of the Grand Duchy of Lithuania. These members belonged to the Clerical Tribunal, which was called Compositi Iudici, meaning the Mixed Court that was made up of secular deputies designated by the marshal of the main Tribunal and of the same number of clerical deputies. ${ }^{56}$ History In the $17^{\text {th }}$ and $18^{\text {th }}$ centuries (until 1793), four secular judges and four clerical judges - two of who were represented by the Cathedral Chapter of Vilnius and two of who were designated by the chapters in Żmudź and Smoleńsk, respectively. This tribunal decided cases in which one of the parties was a member of the clergy. Deputation to the (main) Lithuanian Tribunal was not a permanent office. Members of the capitular delegation were chosen each year and confirmed during the general spring session before the Tribunal's deliberations began and while the assemblies took place in the different counties. The beginning of the term was set for the first Monday after the Feast of

LMAB, f.43-237, ACV, vol. 29 (1767-1777), pgs. 360-361.

LMAB, f.43-238, ACV, vol. 30 (1777-1783), k. 114.

LMAB, f.43-238 - 243, vols. 30-33, passim.

I. Wierzchowiecka, "Organizacja Trybunału Głównego Wielkiego Księstwa Litewskiego (1581-1764)," in Dzieje wymiaru sprawiedliwości, ed.T. Maciejewski, Koszalin 1999, passim. 
Candlemas (February 2). ${ }^{57}$ The Chapter designated some of its members to the Tribunal for the first time on April 7, 1589. The canons Mikołaj Koryzna and Ambroży Bejnart were entrusted with the role and duties of judges while the Tribunal was in session..$^{58}$ Every year, the Chapter appointed members to the delegation; they were almost always canons who were usually elected by seniority or-in rarer instances-personally nominated by the bishop and Chapter. ${ }^{59}$

During the coronation parliament in 1754, the number of judges who served on the Clerical Tribunal of the Tribunal of the Grand Duchy of Lithuania was increased to twelve. In addition to six secular judges, there were also six capitular representatives: three deputies from the Cathedral Chapter of Vilnius as well as two from Żmudź and one from Smoleńsk. ${ }^{60}$ This reform forced the Chapter of Vilnius to call to mind former laws that regulated the sequence in which individuals were delegated to the Tribunal and of determining new assignments in this matter. This did not occur, however, until the general autumn session on October 2, 1792. During this session, the participants came to the agreement that court deputies would constitute a delegation, which had to be made up of one prelate who would be chosen and appointed every year according to his dignity, beginning with the provost prelate, and two canons who were chosen in order of seniority based on who was ordained first. ${ }^{61}$ The Chapter unanimously stipulated that this sequence could be suspended in particular circumstances and that any member of its college could ask to take on this role. During the session, it was also specified that duty of the deputation to the Tribunal also History of the Church pertained to the canon chancellor and the Belarussian archdeacon, even though he did not belong to the Chapter. ${ }^{62}$ During this session,

57 Deputaci Trybunału Głównego Wielkiego Księstwa Litewskiego (1697-1794), ed. A. Rachuba, ed. A. Rachuba, P. P. Romaniuk, Warsaw 2004, Introduction (pgs. 7-18).

LMAB, f.43-215, ACV, vol. 7 (1586-1601), pg. 114.

This is proven by both the minutes that were recorded during the Chapter sessions from 1586-152 (in LMAB, f.43-215 - 235) along with an extremely valuable list of deputies, including priests and religious, to the Tribunal that was prepared by H. Lulewicza, A. Rachubę and P. P. Romaniuka in the publication: Deputaci Trybunatu Gtównego Wielkiego Księstwa Litewskiego (1582-1696) i Deputaci Trybunału Głównego Wielkiego Księstwa Litewskiego (1697-1794), both of which are edited by A. Rachuby.

Deputaci Trybunału Głównego Wielkiego Księstwa Litewskiego (1697-1794), pgs. $10-11$. 
they also confirmed the already-existing practice of giving deputies six weeks payment to cover the cost for food during the court sessions, which the delegates would lose if they did not appear in court. ${ }^{63}$

\section{Other Officials}

The Chapter elected and announced other offices and their corresponding roles during general sessions, in urgent situations, and at ordinary meetings. These offices dealt with contact with certain persons and institutions that were both autonomous from and dependent on the capitular college and that had agendas associated with both the Church and state. They included the deputies of prelates who were given a dignity that was responsible for a particular area of the chapter's activity as a college. They included administrative procurators and commissioners of the capitular benefice; regents and commissioners of the seminary; administrators of student dormitories; members of the college of retired priests; St. Mary Magdalene and St. Roch hospitals; those responsible for the cura animarum in the cathedral; delegates to parliaments and assemblies; delegates to provincial synods; those responsible for contact with the Holy See, nuciatures; and other lesser functions (rather than offices) that appeared over time based on need.

History of the Church

\section{Final Reflections}

As the structure and organization of cathedral chapters evolved due to the changing conditions in which these chapters functioned and to changes that were occuring in general church structures within the dynamic European political landscape, the offices to which prelates elected for this purpose were originally appointed began to be passed on to lower-ranking clergymen who often were not directly members of the Chapter. The prelatures had become titular dignities, and those who possessed them at first then restricted themselves to designating the areas in (and the degree) which the Chapter would be involved, determining ways to realize these aims, and controlling the outcomes of this work. In time, the members began to be involved in matters that had little to do with their original office, which their deputies were left to carry out. It is also a fact that the capitular college of Vilnius was usually made up of men who had reached very advanced age and were ailing (dignities and canons served life-long terms) and who

63 BLAN, f.43-161, De refectionibus et quotidianis distributionibus dandies, XVIII cent., k. 1. 
were aware that the ever-new challenges that the chapter faced were beyond their ability to face.

Therefore, unequivocal assertions that some scholars have made that new offices were created within the Cathedral Chapter of Vilnius were due exclusively to the fact that its members sought to unburden themselves by employing poorly paid officials should, in light of original sources, be made more carefully and formulated less definitively.

\section{Bibliography:}

\section{Archival Sources:}

1. Lietuvos Mokslų Akademijos Vrublevskiu Biblioteka - rankraščiu skyrius (LMAB)

2. Fond 43, nr 155, Statuta inclitae Ecclesiae Cathedralis tam a Venerabili Capitulo quam eius Pontificibusedita tum a Sanctissima Sede Apostolica confirmata, [ok. 1584], (Forma iuramenti a cancellario dioecesano praestandi).

3. Fond 43, no 210-240, Acta Capituli Vilnensis.

4. Fond 43, no 703, Cathalogus cleri vocandi pro Cathedratico [XVII cent.].

5. Fond 43, no 708, Wiadomość o stanie kanclerstwa wileńskiego, b.d.

6. Fond 43 , no 740, Rejestr tak intraty rocznej [...] jako i expens tejże intraty, 1709-1711.

7. Fond 43, no 854, Wiadomości zebrane z papierów kapituły [1732-1820].

8. Fond 43, no 968, Księga dochodów i wydatków, 1771.

9. Fond 43, no 1103, Dekret o deputacji trybunalskiej, 1782.

10. Fond 43, no 1243, Księga przychodów i rozchodów, 1795/1796.

11. Fond 318, no 34673, Opłata refekcjów, 1793.

History of the Church

\section{Printed Sources:}

1. Deputaci Trybunatu Gtównego Wielkiego Księstwa Litewskiego (1582-1696). Edited by A. Rachuba, Compiled by A. Rachuba, P. P. Romaniuk, Warsaw 2007.

2. Deputaci Trybunatu Gtównego Wielkiego Księstwa Litewskiego (1697-1794). Edited by A. Rachuba. Compiled by A. Rachuba, P. P. Romaniuk, Warsaw 2004.

3. Kurczewski, J. Kościót zamkowy czyli katedra wileńska w jej dziejowym, liturgicznym, architektonicznym i ekonomicznym rozwoju, Part 3, Wilno 1916.

4. “Opisanije rukopisnogo otdielenija Wilenskoj Publicznoj Biblioteki, Volume 1, Wilna 1895.

5. Summaryjny wypis z protokołów Kapituty Katedralnej Wileńskiej od r. 1501 do r. 1783 Października 22, przez i. w. Xawierego Bohusza, Pratata Kantora Kathedry Wileńsiey uczyniony." In Opisanie rukopisnago otdielenia Wilenskoj Publicznoj Biblioteki, wypusk 1, Wilna 1895. 


\section{Studies:}

1. Abraham, W. Organizacja Kościoła w Polsce do połowy XII wieku, Poznan 1962.

2. Kasabuła, T. "Kanclerz diecezjalny w kapitule katedralnej wileńskiej w okresie przedrozbiorowym," in "W tym który umacnia." Księga Pamiątkowa ku czci J. E. Ks. Bp. Prof. Edwarda Ozorowskiego. Edited by J. Zabielski, Białystok 2004, pgs. 303-311.

3. Kowalski, M. D. "Początki majątku krakowskiej kapituły katedralnej," in Duchowieństwo kapitulne w Polsce średniowiecznej $i$ wczesnonowożytnej. Pochodzenie i funkcjonowanie elity kościelnej. Edited by A. Radzimiński, Torun 2000, pgs. 69-84.

4. Kurczewski, J. Biskupstwo wileńskie od jego zatożenia aż do dni obecnych, Wilno 1912.

5. Wierzchowiecka, I. “Organizacja Trybunatu Głównego Wielkiego Księstwa Litewskiego (1581-1764)," in Dzieje wymiaru sprawiedliwości. Edited by T. Maciejewski, Koszalin 1999.

6. Zachorowski, S. Rozwój i ustrój kapituł polskich w wiekach średnich, Cracow 1912. 